\title{
Efficiency and Competition in the Malaysian Banking Market: Foreign versus Domestic Banks
}

\section{Rossazana Ab. Rahim}

Department of Economics, University Malaysia Sarawak, Malaysia

\begin{abstract}
The aim of this paper is to investigate how efficient the performance of the Malaysian banking market is, using a data envelopment analysis approach, in the context of the increasing presence of foreign banks. Specifically, two measures of efficiency are constructed, cost and profit efficiency, by utilizing bank-level data from Malaysian commercial banks, over the period from 2003 to 2014. The results obtained show the domestic banks are more efficient than their foreign banking counterparts for both measures of efficiency. Next, the Lerner index approach was employed to measure competition and finally, Granger causality tests were undertaken to answer the question, does competition foster efficiency? The results of the causality tests support a positive effect of competition on the cost and profit efficiency of Malaysian banks. With regard to the financial liberalization, the findings imply that higher competitive pressure may offset the market power of individual banks; however, eventually it will result in efficiency gains for the Malaysian banks.
\end{abstract}

Keywords: competition; efficiency; Malaysian banks

JEL classification: D43, L12, G32

* Corresponding author's e-mail: rossazana@gmail.com 


\section{Introduction}

The presence of foreign banks in emerging markets and developing countries has increased sharply, with market shares of 36 percent and 45 percent in 2009, up from 18 percent and 24 percent in 1995; foreign banks play important roles in financial intermediation, with their average loan, deposit and profit shares being between 42 percent and 50 percent (Claessens and Van Horen 2013). The greater openness to foreign banks has at times been motivated by a need to improve the levels of competition and the banking system's efficiency and soundness; additionally, the change in policy has also been triggered by the need to reduce the costs of restructuring and recapitalizing banks in the aftermath of economic crises and the desire to build a banking institutional structure that is more robust to future economic shocks (Lindgren et al. 1996).

In the same vein, Malaysia is opening up its banking system to foreign investors as part of the country's efforts to expedite its integration into the so-called ASEAN Economic Community (AEC) in 2015. ${ }^{1}$ The ASEAN Economic Integration Plan, which is based on the AEC Blueprint and ASEAN Framework Agreement on Services (AFAS) in particular, will facilitate financial liberalization in the region. In April 2009, financial liberalization was announced in the Malaysian banking market; foreign banks were now allowed to own up to 70 percent equity (pre- viously 49 percent) in investment banks, Islamic banks, insurance companies, and Takaful operators. ${ }^{2}$ As part of the liberalization package, seven new licenses were issued to foreign banks, five new licenses were given to conventional foreign banks with paid-up capital of RM300 million, and two new licenses were given to mega Islamic banks with paid-up capital of RM3.27 billion. In June 2010, a further five new licenses were given to BNP Paribas SA (France), Mizuho Corporate Bank (Japan), National Bank of Abu Dhabi (United Arab Emirates), PT Bank Mandiri (Indonesia) and Sumitomo Mitsui Banking Corporation (Japan). On this note, the banking sector received a greater inflow of foreign investment into the sector and the foreign banks now dominate the domestic banks in the Malaysian banking market. The presence of more foreign banks in the market will enhance banking competition, add to the diversity of the financial services industry and facilitate the transformation of the Malaysian economy to achieve developed high-income economy status by 2020 .

The presence of foreign banks in Malaysia has increased steadily since the banking reform which was actuated by the economic malaise at the end of 1997 . The crisis demonstrated the vulnerabilities of domestic banking institutions; large numbers of fragile commercial banks and finance companies were revealed and the insolvency and financial distress were chaotic. The enforcement of Malaysia's bank mergers resulted in the

\footnotetext{
${ }^{1}$ ASEAN which stands for the Association of Southeast Asian Nation was established in August 1967 and the initial members were Malaysia, the Philippines, Thailand, Indonesia and Singapore. The establishment of ASEAN was motivated by three factors: to assuage intra-ASEAN tensions, to promote the socio-economic development of member countries and to reduce the regional influence of external factors.

${ }^{2}$ Takaful is defined as an Islamic insurance concept which refers to the management of funds in the contract between participants and the operator grounded in the rules and regulations of Shariah (Islamic law); the basic principles behind Islamic banking are the sharing of profit and loss and the prohibition on the collection and payment of interest. To put it simply, Islamic banking is also known as Shariah compliance banking.
} 
joining of all the domestic commercial banks into several merged entities. Prior to the merger announcement, the government's policy had been to allow market forces to dictate mergers. Even with the government's efforts, the banking institutions were sluggish in responding to the call for mergers. Table 1 illustrates the slow reduction in the number of banking institutions during the period from 1980 through to 1999.

Table 1 shows that 71 banking institutions, with 2,712 branches, operated in the country in 1999. Between 1980 and 1999, the number of domestic banks and merchant banks remained relatively constant at 21 and 12 , respectively. Malaysia was clearly over- supplied with banks and this led to the inefficient use of resources, and the duplication of resources and infrastructure in the domestic market (Central Bank of Malaysia 1999). The enforcement of bank mergers in 1999 reduced the number of domestic banks to ten, while the number of foreign banks was left untouched. The merger process continued in 2006 when Southern Bank was acquired by another anchor bank, CIMB Bank. Another voluntary merger took place in 2011 when Hong Leong Bank acquired EON Bank; as a result, there are only 8 domestic banks at present, as compared with 19 commercial banks owned by foreign stakeholders. ${ }^{3}$

\section{Table 1. The Number of Banking Institutions (1980 - 1999)}

\begin{tabular}{ccccc}
\hline Banking Institutions & $\mathbf{1 9 8 0}$ & $\mathbf{1 9 9 0}$ & $\mathbf{1 9 9 9}$ & $\mathbf{2 0 1 4}$ \\
\hline Commercial Banks & & & & \\
Domestic & 21 & 22 & 21 & 8 \\
Foreign & 17 & 16 & 13 & 19 \\
Finance Companies & 47 & 45 & 25 & - \\
Merchant Banks $^{\mathrm{b}}$ & 12 & 12 & 12 & 13 \\
Islamic Banks $^{\mathrm{c}}$ & & & & \\
$\quad$ Domestic & - & 1 & 12 & 10 \\
$\quad$ Foreign & - & - & 3 & 10 \\
Total & 99 & 97 & 73 & 60 \\
\hline
\end{tabular}

Note: ${ }^{\text {a }}$ All previous finance companies have been acquired by respective anchors (commercial banks).

b. All merchant banks have been converted or merged into investment banks.

c. On 4 March 1993, the Central Bank of Malaysia introduced an interest-free banking scheme, popularly known as Islamic windows, which has allowed commercial banks to offer Islamic products side by side with two fullfledged Malaysian Islamic banks: Bank Islam and Bank Muamalat.

Source: Central Bank of Malaysia (1999, 2015).

${ }^{3}$ It is interesting to note that merger fever has hit the Malaysian banking sector; a plan to merge three Malaysian banks to create the biggest bank in Malaysia specifically and Southeast Asia in general was unveiled in 2014. The marriage plan involves CIMB bank, RHB Capital and Malaysia Building Society with combined assets of RM613 billion (USD \$188 billion); nevertheless, to date the plan still faces difficulties in arriving at a value-creating transaction for all stakeholders (The Star Online 2015). Thus, most likely, the plan will not be implemented despite the Central Bank of Malaysia moving to create regional giant banks in realising the vision of the ASEAN Economic Community in 2015. 
Past studies into the role of foreign banks are dominated by research in the advanced countries, particularly the United States (US) and Europe, and to a lesser degree in developing countries. Generally, foreign banks in developed countries are less efficient than domestic banks; nevertheless, banks from certain countries are more efficient than their counterparts in other developed countries (Berger et al. 2000). Even though the research in developing markets lags far behind, the findings support the contention that foreign banks in these countries have succeeded in exploiting their comparative advantages and show higher efficiency than their domestically owned counterparts (Isik and Hassan 2002; Grigorian and Manole 2002; Hasan and Marton 2003). Foreign banks do not just follow their customers into developing markets; rather, they are more interested in exploiting local opportunities (Clarke et al. 2001).

The proponents of foreign bank entry argue that foreign banks benefit the domestic banking market; the presence of foreign banks is claimed to enhance competition in the local banking market (Jeon et al. 2011) and eventually improve the efficiency of domestic banking operations and increase the availability of credit (Claessens et al. 2001; Clarke et al. 2001; Levy-Yeyati and Micco 2007; Yildirim and Philippatos 2007; Claessens 2009; Olivero et al. 2009; Wu et al. 2010). For instance, a cross-country study shows that the presence of foreign bank has been associated with lower profitability and lower overhead expenses for the domestic banks, and hence with enhanced domestic banking efficiency (Claessens et al. 2001). The penetration of foreign banks into the domestic banking market increases the inflow of available capital for domestic investments; foreign banks contribute to the stability of capital inflows by diversifying the funding supply of domestic credit (Dages et al. 2000). Other arguments in favor of foreign bank entry into the local banking market include improving risk management, transferring the financial system's supervision and supervisory skills from the parent country, boosting the efficiency of resources allocations, stabilizing the domestic banking markets and mitigating the credit crunch and banking crises in host countries (e.g. Crystal et al. 2002; Claessens and Laeven 2005; Claessens and van Horen 2013; Wu et al. 2010; Jeon et al. 2011). ${ }^{4}$

Opponents of the growing participation of foreign banks in domestic markets are concerned that the foreign banks might reverse their capital and credit flows during a major crisis in the host country; thus they would not be able to provide sustainable funding to the local market. Foreign-owned banks might hamper the stability of the domestic banks' credit through capital flight. If the parent banks in their home countries suffer a credit crunch or capital loss, the foreign banks can contribute to any instability in the domestic banking market by linking the domestic country with the cyclical fluctuations of the foreign country (Morgan and Strahan 2003). Jeon and Wu (2014) offer evidence that foreign banks are a major channel for the transmission of financial shocks, and pose a significant challenge to the effectiveness of monetary policy in the host economies. Foreign banks may also cherry-pick the most remunerative domestic projects or high-quality borrowers; thus, the domestic banks may

${ }^{4}$ Interested readers are referred to Claessens and van Horen (2013) for a comprehensive study, covering 1995-2009 and including 5,324 banks in 137 countries, on the impacts of foreign banks on domestic financial institutions. 
be forced to serve high-return clients. Foreign banks also have limited information on the creditworthiness of smaller borrowers in local markets and tend to have higher interest margins and profitability than domestic banks. As a result, domestic banks become unprofitable, inefficient and less competitive (de la Torre et al. 2010; Moguillansky et al. 2004; Barajas et al. 2000). Other concerns about the drawbacks of foreign banks' presence are based on the idea that local financial institutions should be dominated and controlled by domestic stakeholders that serve the host countries' interests (Dages et al. 2000).

Based on the above mentioned studies, the extant literature has focused on the impacts, advantages, and drawbacks of the growing role of foreign banks in local banking markets; nevertheless, to the best of this author's knowledge, no studies have investigated the nexus between efficiency and competition in a comparison between domestic and foreign banks. Past studies such as Havrylchyk (2006) reports evidence that foreign banks have achieved higher levels of efficiency than domestic banks; however, foreign banks that acquired domestic Polish banks have not improved their efficiencies. Foreign banks are also more efficient than domestic banks in Latin America and the Caribbean (Sáez-Fernández and PicazoTadeo 2012). Claessen et al. (2002) suggests that the increasing presence of foreign banks leads to reductions in profitability and margins for domestic banks. In addition, Dages et al. (2000) presents evidence of the contribution of foreign-owned banks to greater stability of credit and improved financial systems in Argentina and Mexico. Another stream of studies begs to differ; Wezel 2010 discovers that foreign banks in Central America are not necessarily more efficient than their domestic counterparts. Saif and Yassen (2005) also find that the performance efficiency of foreign banks is no different to that of the domestic banks in the Middle East and North Africa (MENA) region. In a crosscountry analysis, Lensik et al. (2008) confirms the argument of opponents, that foreign banks negatively affect banking efficiency; Liao (2010) also expresses similar support for the contention.

As far as this study is concerned, there has been no attempt at all to assess the nexus between efficiency and competition in the context of the foreign banks and their domestic counterparts in the Malaysian banking system. Detragiache and Gupta (2004) report that foreign banks appear to perform better than domestic banks during a financial crisis, in terms of their capitalization, profitability and interest margin, and worse in terms of overhead expenses. Matthew and Mahadzir Ismail (2006) find that the main source of productivity growth in Malaysian banking is technical change, and foreign banks are more efficient than domestic banks in this respect. The contention that foreign banks are more efficient than domestic banks is also supported in Onget al. (2011). Their findings indicate that foreign banks are more efficient than domestic banks with respect to Automated Teller Machine (ATM) utilization and profit generation. Mohd-Tahiret al. (2010) suggests that domestic banks are less profit efficient than foreign banks. Most of these previous studies have reported that foreign banks are more efficient than domestic banks. Therefore, this study seeks to fill this gap in the literature by providing evidence regarding the efficiency and competition nexus of the Malaysian banking industry through a comparison between the foreign banks and their domestic counterparts. 
The rest of this paper is organized as follows. The next section offers a brief discussion of the literature review of the nexus between competition and efficiency in the banking sector, followed by a section describing the data and the methodology. The results and discussion section presents the results of the market structure and competition, as well as the nexus between the various measures of efficiency and banking competition. The article ends with the conclusion.

\section{Literature Review}

Basically, two strands of literature on the efficiency-competition link in banking exist: One that involves the structural approach and the other that involves the nonstructural approach. Both structure-conductperformance and efficient-structure theories, which form the structural approach, postulate that market concentration determines the competitive conduct of firms in a market. The rationale behind the link between market competition and efficiency originates from the 'Quiet Life Hypothesis' (QLH), which the great Hicks states as "The best of all monopoly profits is a quiet life" (Hicks 1935, p. 35). The hypothesis suggests that there is less pressure to compete in concentrated markets, which results in reduced efforts by managers to operate efficiently. Therefore, an increased market concentration weakens market competition and hampers productive efficiency. The QLH also constitutes the 'Structure Conduct Performance' (SCP) hypothesis as proposed by Bain (1951). This hypothesis advocates that banks in a concentrated market impose higher loan rates and lower deposit rates, generating more profits and reducing collusion costs, and as a result, competition declines. Basically, the SCP paradigm suggests that markets which are dominated by a few large firms (highly concentrated) are less competitive than markets which are less concentrated (Mason 1939); an increase in market concentration is associated with higher prices and greater profits (Bain 1951). In contrast, the 'Efficient Structure Hypothesis' (ESH) infers that the degree of concentration is determined by the superior performance of the efficient banks. The hypothesis postulates that firms with superior efficiency become more profitable and thus will increase their market share; as a result, competition declines (Demsetz 1973; Peltzman 1977). Firms may be exploiting greater x-efficiency or greater scale efficiency (Berger 1995); therefore, more efficient firms implies that they have lower costs which enables them to capture a larger market share, resulting in a higher market concentration.

The second approach, the non-structural approach, suggests that no clear evidence exists showing that in more concentrated markets the market power is higher and competition is lower. The contestable market theory emphasizes that a high concentration market can be highly competitive even if it is dominated by only a few firms (Baumol 1982). In addition, Liebenstein (1966) argues that competition can reduce $\mathrm{x}$-inefficiencies. This approach does not infer the competitive conduct of banks based on the market structure; the new industrial organization approach claims that banks behave differently depending on the market structure in which they operate.

Another stream of studies regresses the efficiency scores over the non-structural measures of the Panzar-Rosse approach. For instance, Weill (2004) incorporates efficiency scores (measured by a stochastic frontier method) and a set of independent variables (Gross Domestic Product \{GDP\} per capita, density of demand, intermediation ratio and 
geographic location) against the regression of the competition variable. That study found a negative relationship between competition and efficiency in the European Union (EU) banking market. This is supported by Casu and Girardone (2006), who measured competition by the Panzar-Rosse approach where data development analysis was employed to estimate efficiency scores. The study offers evidence of a negative relationship between efficiency and competition in the EU banking market (1997-2003). In a study of the South African banking market, Mlambo and Ncube 2011 find that the South African banking sector is characterized by a monopolistic competition market structure, while there is an increasing trend in banking efficiency for 1999-2008. In contrast to Casu and Girardone (2006), the authors propose a positive relationship between efficiency and competition in the South African banking market.

Empirical studies that test the running causality between efficiency and competition are scarce. The most notable study is Casu and Girardone (2009), which reveals the causality relationship by employing Granger causality tests. That study found a negative relationship between efficiency and competition in selected EU countries (France, Germany, Italy, Spain and the United Kingdom) in 2000-2005. The authors find a positive causation between market power and efficiency, whereas the causality running from efficiency to competition is weak. Next, PruteanuPodpiera et al. (2008) investigated the effects of banking competition on efficiency measures in the Czech Republic between 1994 and 2005. That study rules out competition improvements over the study period. The results offer support for a negative relationship between cost efficiency scores and banking competition; thus, the 'quiet life' hypothesis is rejected. Maudos and Fernándezde
Guevara (2007) analyzed the relationship between market power and efficiency in the EU countries from 1993 to 2002. They regressed market power variables, represented by the Lerner index and HirschmanHerfindahl Index (HHI) and other explanatory variables (size of banks and types of banking specialization), on the dependent variable, which was the cost efficiency variable. The results of the study reject the 'quiet life' hypothesis in the European banking system.

By pointing out the gap in the literature regarding the link between competition and bank soundness, Schaek and Cinak (2008) employed efficiency measures as the possible transmission mechanism by which higher competition contributed to increased bank soundness in European and US markets in 1995-2005. Employing the Lerner index as the measure of competition and cost and profit efficiency, which are measured by the stochastic frontier method, the study applied Granger causality tests to examine the link between competition and efficiencies. The negative running causality from cost efficiency to competition is confirmed in both markets. However, the running causality of 'competition-cost efficiency' yields different signs, a positive link in the US, but the reverse recorded in the European market. That study offers support for the pro-competition policies by suggesting that competitive banks are able to allocate resources more efficiently to bank customers. The testimony is confirmed further in the study by Koetter et al. (2008) of the US banking market between 1986 and 2005.

This study contributes to the literature by extending the analysis of the relationship between efficiency and competition to developing countries, specifically the Malaysian banking market. This is the first empirical 
study to test the relationship between efficiency and competition in the Malaysian banking industry.

\section{Methods}

\section{Input and Output Variables}

The definition and measurement of inputs and outputs in the banking function remains a contentious issue among researchers. ${ }^{5}$ There is a long-standing dispute over what banks produce and what resources banks consume (Berger and Humphrey 1992). With regard to this, there are two main approaches in the banking theory literature, namely the production and intermediation approaches (Klein 1971; Monti 1972; Sealey and Lindley 1977). As the purpose of this study is to evaluate the efficiency of banks, with banks acting as financial intermediaries, this study employs the intermediation approach, like many studies into banking efficiency (such as Omar, Abd-Majid and Rulindo, 2007; Sufian and Abd-Majid, 2007; Abd-Majid and Maulana, 2012 among all). It is also more relevant for financial institutions, as the cost of funds to be intermediated (interest expenses) often accounts for one-half to two-thirds of their total costs (Berger and Humphrey 1997). This approach is also superior at evaluating the importance of frontier efficiency, as the minimization of total cost (besides production cost) is needed to maximize profits.

The input variables chosen are personnel expenses, fixed assets, deposits and short term funding (deposits), whereas the output variables are represented by total loans and total securities. Subsequently, the intermediation approach is maintained in the estimation of competition in the Malaysian banking sector. The input prices employed are calculated as the price of labor (total expenditure on employees such as salaries, employee benefits and reserves for retirement pay, divided by total assets); the price of capital (the ratio of non-interest expenses to the book value of premises and fixed assets) and the price of deposits (total interest expenses divided by total deposits and short-term funding), while the output prices are proxied by the ratio of total income and total loans and advances (price of loans) and the ratio of non-interest income and total securities (price of securities).

This study covers 21 Malaysian commercial banks over the period from 2003 to 2014; including all the domestic banks, namely: Affin Bank, Alliance Bank, AMBank, CIMB Bank, Hong Leong Bank, Maybank, Public Bank and RHB Bank and 13 foreign banks: Bangkok Bank, Bank of America, Bank of China, Bank of Tokyo-Mitshubishi, Citibank, Deustche Bank, Hongkong and Shanghai Banking Corporation (HSBC) Bank, J.P. Morgan Chase Bank, Oversea-Chinese Banking Corporation (OCBC) Bank, Standard Chartered Bank, the Bank of Nova Scotia, the Royal Bank of Scotland and United Overseas Bank. ${ }^{6}$ The bank level data used are taken from the BankScope 2000 spreadsheets published by Bureau Van Dijk (BVD). All the financial variables reported

${ }^{5}$ Interested readers are referred to Berger and Mester (2003) for a competent treatment of the definitions and measurement of the concepts of bank inputs and outputs.

${ }^{6}$ Six foreign commercial banks are not included in this study as the respective banks were established quite later on in the study period. For instance, five banks namely: BNP Paribas SA (France); Mizuho Corporate Bank (Japan); National Bank of Abu Dhabi (United Arab of Emirates); Industrial and Commercial Bank of China and Sumitomo Mitsui Banking Corporation (Japan) were set up in 2010 while another bank, India International Bank was just established in 2011. 
are in nominal values (Ringgit Malaysia), to facilitate comparison over time, and all the variables are deflated by the Consumer Price Index (hereafter denoted as CPI) to obtain real values at the 2010 price constant. $^{7}$

\section{Measuring Efficiency}

The main nonparametric method, Data Envelopment Analysis (DEA), was introduced by Charneset et al. (1978) and it is an analytical tool used to measure the relative efficiency of firms throughout the process of transforming inputs into outputs. The efficiency score is obtained by taking the maximum ratio of weighted outputs to weighted inputs. This measurement allows multiple outputs and inputs to be reduced to a single 'virtual' input $\left(x_{i}\right)$ and a single 'virtual' output $\left(y_{i}\right)$ by optimal weighs. This study utilizes the variable returns to scale model (Banker et al. 1984) as in practice firms may face either economies or diseconomies of scale. Additionally, the input-oriented DEA is employed in this study as the domestic commercial banks dwell well on the sources of input waste (Isik and Hasan 2003). There exist N firms $(i=1, \ldots, N)$ that produce a vector of q outputs $y_{i}=\left(y_{i}, \ldots, y_{i q}\right)$ that they sell at prices $r_{i}=\left(r_{i p}, \ldots, r_{i 0}\right)$ using a vector of $\mathrm{p}$ inputs $x_{i}=$ $\left(x_{i p}, \ldots, x_{i p}\right)$ for which they pay prices $\mathrm{w}_{i}=$ $\left(w_{i p}, \ldots, w_{i p}\right)$. To account for cost efficiency, the vector of input prices $w_{i}$ is inserted into the equation; the cost efficiency for the case of firm $j$ can be calculated by solving the following linear programming:

$$
\begin{aligned}
& \text { Minimize } \sum_{p} w_{p j} x_{p j} \\
& \text { s.t. } \sum_{i} \lambda_{i} y_{i q} \geq y_{j q} \quad \forall q
\end{aligned}
$$

$$
\begin{aligned}
& \sum_{i} \lambda_{i} x_{i p} \leq x_{j p} \quad \forall p \\
& \sum_{i} \lambda_{i}=1 ; \lambda_{i} \geq 0 ; \quad i=1, \ldots, N
\end{aligned}
$$

where $x_{j}^{w}$ is the cost minimizing vector of the input quantities for the $j$ th $\mathrm{DMU}$, given the input prices $w_{i}$ and the output levels $y_{i}$ are obtained from a linear combination of firms that produce at least as much of each of the outputs using the same or less amount of inputs. Having obtained the solution to the problem, the cost efficiency of firm $j$ is calculated as:

$$
C E_{j}=\frac{C_{j}^{*}}{C_{j}}=\frac{\sum_{p} w_{p j} w_{p j}^{*}}{\sum_{p} w_{p j} x_{p j}} \ldots \ldots \ldots \ldots \ldots \ldots
$$

where $\mathrm{CEj} \leq 1$ represents the ratio between the minimum costs associated with the use of the input vector that minimizes costs and the observed costs for firm $j$.

Similarly to cost efficiency, the calculation of standard profit efficiency can be done, for the case of firm j, by solving the following problem of linear programming proposed by Chung et al. (1997). This solution is obtained from a linear combination of firms that produce at least as much of each of the outputs using the same or less amounts of inputs. If this hypothetical firm is subject to the same input and output prices as those faced by firm $j$ it would have a profit:

$$
\begin{aligned}
\operatorname{Maximize} & \sum_{q} r_{q j} y_{q j}-\sum_{p} w_{p j} x_{p j} \\
\text { s.t. } & \sum_{i} \lambda_{i} y_{i q} \geq y_{j q} \quad \forall q
\end{aligned}
$$

\footnotetext{
${ }^{7} \mathrm{CPI}$ is preferred for use as the deflator in many studies such as Dogan and Fausten (2003) and Detragiache and Gupta (2004). Okuda and Hashimoto (2004) stated that when using panel data, it is necessary to use a deflator in order to keep outputs from various years comparable.
} 


$$
\begin{aligned}
& \sum_{i} \lambda_{i} x_{i p} \leq x_{j p} \quad \forall p \\
& \sum_{i} \lambda_{i}=1 ; \lambda_{i} \geq 0 ; \quad i=1, \ldots, N
\end{aligned}
$$

which corresponds to the vector of outputs and the input demand vector that maximizes the profits with the given prices of outputs $r$ and inputs $w$. This solution is obtained from a linear combination of firms that produce at least as much of each of the outputs using the same or less amounts of inputs; thus, it would have a profit which will be higher than or equal to that of firm $j$.

Having solved the above problem, the standard profit efficiency for firm $j$ is then calculated as follows:

$$
P E_{j}=\frac{P_{j}}{P_{j}^{*}}=\frac{\sum r_{q j} \cdot Y_{q j}-\sum w_{p j} \cdot x_{p j}}{\sum r_{q j} \cdot y_{q j}^{*}-\sum w_{p j} \cdot x_{p j}^{*}} \ldots \ldots . .(4)
$$

where $P E_{j}$ represents the ratio between the observed profits $P_{j}$ and the maximum profits associated with the production of the output vector and with demand for inputs that maximize profits for firm $j$.

\section{Measuring Market Structure}

To measure market share in an industry, a market concentration ratio is used. $\mathrm{CR}_{\mathrm{k}}$ is computed as the sum of the $k$ largest firms' market shares in the market, which takes the form:

$$
\mathrm{CR}_{\mathrm{k}}=\sum_{\mathrm{i}}^{\mathrm{k}} \mathrm{s}_{\mathrm{i}}
$$

Next, HHI is utilized to capture the general features of the market's structure. HHI refers to the sum of the squared market share of all the banks in the market, where the market shares are considered as weights. The formula is given as follows:

$$
\mathrm{HHI}=\sum_{\mathrm{i}}^{\mathrm{n}} \mathrm{s}_{\mathrm{i}}^{2}
$$

where is the sum of squared market shares of the $i$ th firm, and $n$ is the number of firms in the market.

\section{Measuring Competition}

To measure bank competition, this study utilizes the Lerner index of monopoly power; the index is a non-structural indicator of the degree of market competition. The computation of the index provides measures of competition at the firm level, and the index has been employed in several empirical studies into banking competition (e.g. Angelini and Cetorelli 2003; Maudos and Fernándezde Guevara 2007; Fernándezde Guevara et al. 2005.). Basically, it is defined as the difference between price (calculated as the ratio of total costs to total assets) and marginal cost (expressed as a percentage of prices) divided by price; it can be expressed mathematically as:

$$
\text { Lerner }_{i t}=\frac{\mathrm{p}_{\mathrm{i}}-\mathrm{MC}_{\mathrm{it}}}{\mathrm{p}_{\mathrm{i}}}
$$

where $p_{i}$ is the price of the total assets of production output $Q$, and is calculated as total revenue (interest plus non-interest income) divided by total assets. If the Lerner index is equal to zero; it indicates perfect competition, so the firm has no market power, while an index value of closer to one indicates relatively weak price competition, and thus the firm has market power. Additionally, the Marginal Cost (MC) is obtained by taking the first derivative of the translog cost function with respect to output, as in Equation (10):

$$
\mathrm{MC}_{\mathrm{it}}=\frac{\mathrm{TC}_{\mathrm{it}}}{\mathrm{Q}_{\mathrm{it}}}\left(\alpha_{1}+\alpha_{2} \ln \mathrm{Q}_{\mathrm{it}}+\alpha_{3} \ln \mathrm{Q}_{\mathrm{it}}+\alpha_{24} \ln \mathrm{Q}_{\mathrm{it}}+\varepsilon_{\mathrm{it}}\right)
$$


To derive the marginal cost, a translog cost function is adopted as it does not require too many restrictive assumptions about the nature of the technology. The multi product cost function for a given bank $i$ at time $t$ follows Pruteanu-Podpiera et al. (2008) as specified below:

$$
\begin{aligned}
\ln T C_{i t}= & \alpha_{0}+\sum_{j=1}^{2} \alpha_{j} \ln y_{j i t} \\
& +\frac{1}{2} \sum_{j=1}^{2} \sum_{k=1}^{2} \alpha_{j k} \ln y_{j i t} \ln y_{k i t} \\
& +\sum_{m=1}^{3} \beta_{m} \ln w_{m i t} \\
& +\frac{1}{2} \sum_{m=1}^{3} \sum_{n=1}^{3} \beta_{m n} \ln y_{m i t} \ln w_{n i t} \\
& +\sum_{j=1}^{2} \sum_{m=1}^{3} \delta_{j m} \ln y_{j i t} \ln w_{m i t}+v_{i t}+\mu_{i t}
\end{aligned}
$$

Total costs (TC) of banks are functioned to output or total loans $(y)$, the input prices (w) which are $P_{L}$ as the price of labor, $P_{K}$ as the price of physical capital and $P_{D}$ as the price of borrowed funds; whilst $\alpha=1,2$, ..., 9 are the parameters to be estimated. $v_{i t}$ is a two-side error term to capture the effects of statistical noise, assumed to be independently and identically normal, distributed with zero mean and a variance $\alpha^{2}$ and independent of the $u_{s t}$ Standard symmetry restrictions of linear homogeneity in input prices are imposed by normalizing total costs and input prices with one input price $\left(P_{D}\right)$. The symmetry condition requires

$$
\alpha_{i k}=\alpha_{k i} \forall i, k \text { and } \beta_{j m}=\beta_{m j} \forall j, m \text {. }
$$

\section{Empirical Models}

This study employs a panel least-squares regression using the Granger causality test to assess the causality between bank competition and bank efficiency. $A$ variable $X$ Granger causes variable $Y$ if past values of variable $X$ should contain information that helps predict or better explain the present value of variable $Y$. The Granger causality test indicates that changes in one variable precede changes in another variable of interest. Inferences on causality is achieved by running Wald tests on the coefficients of the lagged $X$ and lagged $Y$ in order to check whether they are jointly statistically different from zero (Casu and Girardone 2009). Following the framework of Pruteanu-Podpiera et al. (2008) and Casu and Girardone (2009), using the Eviews 8.0 software, the panel data model is used to assess the Granger causal relationship between the efficiency and competition of the banks as follows:

$$
\begin{aligned}
& \mathrm{Y}_{\mathrm{it}}=\sum_{\mathrm{j}=1}^{\mathrm{n}} \alpha_{i} y_{\mathrm{it}-\mathrm{j}}+\sum_{\mathrm{j}=1}^{\mathrm{n}} \beta_{i} \mathrm{x}_{\mathrm{it}-\mathrm{j}}+\eta_{i}+v_{i t} \\
& \mathrm{x}_{\mathrm{it}}=\sum_{\mathrm{j}=1}^{\mathrm{n}} \delta_{i} \mathrm{x}_{\mathrm{it}-\mathrm{j}}+\sum_{\mathrm{j}=1}^{n} \tau_{i} \mathrm{y}_{\mathrm{it}-\mathrm{j}}+\eta_{i}+\xi_{i t}
\end{aligned}
$$

where $i$ represents the individual bank and $t$ denotes time while $\alpha_{j} \beta_{j} \delta_{i}$ and $\tau_{i}$ are the parameters to be estimated; while $\eta_{I}$ stands for the bank's individual effect; $v_{i t}$ and $\xi_{i t}$ are error terms. The error terms in Equation (10) and Equation (11) are assumed to be normally distributed with a mean of zero and constant variance. Each dependent variable is regressed on its yearly lags and on those of the other variable. 
Table 2. Descriptive Statistics of Input and Output Variables

\begin{tabular}{|c|c|c|c|c|c|}
\hline Variable Description & Mean & Median & Minimum & Maximum & $\begin{array}{l}\text { Standard } \\
\text { Deviation }\end{array}$ \\
\hline \multicolumn{6}{|l|}{ All Banks: } \\
\hline \multicolumn{6}{|l|}{ Inputs: } \\
\hline Personnel expenses & 137.23 & 71.53 & 1.22 & $1,181.20$ & 208.23 \\
\hline Fixed assets & 82.56 & 40.14 & 0.20 & 718.09 & 116.93 \\
\hline Total deposits & $15,600.05$ & $8,430.83$ & 132.14 & $112,051.06$ & $21,298.44$ \\
\hline \multicolumn{6}{|l|}{ Outputs: } \\
\hline Loans and advances & $11,204.03$ & $5,657.85$ & 8.56 & $91,257.92$ & $16,414.90$ \\
\hline Securities portfolio & $3,112.81$ & $1,618.08$ & 10.67 & $30,692.82$ & $4,531.88$ \\
\hline \multicolumn{6}{|l|}{ Input Price: } \\
\hline Price of labor & 0.0097 & 0.0064 & 0.0013 & 0.3020 & 0.0294 \\
\hline Price of capital & 3.8513 & 1.9165 & 0.1814 & 35.3143 & 5.0467 \\
\hline Price of deposits & 0.0243 & 0.0237 & 0.0019 & 0.1006 & 0.0108 \\
\hline \multicolumn{6}{|l|}{ Output Price: } \\
\hline Price of loans & 0.2363 & 0.0907 & 0.0326 & 5.5925 & 0.5725 \\
\hline Price of securities & 0.1326 & 0.0953 & $(0.5655)$ & 2.6533 & 0.2072 \\
\hline \multicolumn{6}{|l|}{ Domestic Banks: } \\
\hline \multicolumn{6}{|l|}{ Inputs: } \\
\hline Personnel expenses & 285.71 & 183.79 & 41.13 & 1181.20 & 270.41 \\
\hline Fixed assets & 177.72 & 167.02 & 29.41 & 718.09 & 140.02 \\
\hline Total deposits & $32,033.42$ & $22,755.78$ & $3,762.05$ & $112,051.06$ & $26,090.47$ \\
\hline \multicolumn{6}{|l|}{ Outputs: } \\
\hline Loans and advances & $23,548.72$ & $15,986.86$ & $2,817.92$ & $91,257.92$ & $20,553.53$ \\
\hline Securities portfolio & $6,496.76$ & $4,555.00$ & 572.37 & $3,0692.82$ & $5,786.04$ \\
\hline \multicolumn{6}{|l|}{ Input Price: } \\
\hline Price of labor & 0.0157 & 0.0072 & 0.0013 & 0.3020 & 0.0471 \\
\hline Price of capital & 1.4547 & 1.4126 & 0.5022 & 3.2054 & 0.6142 \\
\hline Price of deposits & 0.0255 & 0.0255 & 0.0145 & 0.0389 & 0.0058 \\
\hline \multicolumn{6}{|l|}{ Output Price: } \\
\hline Price of loans & 0.0877 & 0.0864 & 0.0534 & 0.1534 & 0.0159 \\
\hline Price of securities & 0.0870 & 0.0824 & -0.1847 & 0.2347 & 0.0548 \\
\hline \multicolumn{6}{|l|}{ Foreign Banks: } \\
\hline \multicolumn{6}{|l|}{ Inputs: } \\
\hline Personnel expenses & 45.86 & 12.39 & 1.22 & 217.95 & 57.82 \\
\hline Fixed assets & 24.00 & 4.78 & 0.20 & 122.89 & 32.63 \\
\hline Total deposits & $5,487.21$ & $1,500.95$ & 132.14 & $29,131.70$ & $6,868.57$ \\
\hline \multicolumn{6}{|l|}{ Outputs: } \\
\hline Loans and advances & $3,607.30$ & 739.54 & 8.56 & $23,520.08$ & $4,994.72$ \\
\hline Securities portfolio & $1,030.38$ & 384.67 & 10.67 & $4,168.99$ & $1,132.47$ \\
\hline \multicolumn{6}{|l|}{ Input Price: } \\
\hline Price of labor & 0.0060 & 0.0059 & 0.0019 & 0.0112 & 0.0019 \\
\hline Price of capital & 5.3261 & 3.2508 & 0.1814 & 35.3143 & 5.9385 \\
\hline Price of deposits & 0.0235 & 0.0220 & 0.0019 & 0.1006 & 0.0129 \\
\hline \multicolumn{6}{|l|}{ Output Price: } \\
\hline Price of loans & 0.3278 & 0.1005 & 0.0326 & 5.5925 & 0.7131 \\
\hline Price of securities & 0.1607 & 0.1084 & -0.5655 & 2.6533 & 0.2561 \\
\hline
\end{tabular}

Note: Price of inputs consist of price of labor (total expenditure on employees such as salaries, employee benefits and reserves for retirement pay, divided by total assets); price of capital (the ratio of non-interest expenses to the book value of premises and fixed assets) and price of deposits (total interest expenses divided by total deposits and short-term funding); while output prices are price of loan (the ratio of total income and total loans and advances) and price of securities (the ratio of non-interest income and total securities). 


\section{Result and Discussion}

\section{Descriptive Statistics}

This section presents the descriptive statistics of the input and output variables. The input variables consist of the total personnel expenses, total fixed assets, and total deposits, while the security portfolios, and total loans and advances represent the output variables. All the financial variables are reported in RM values (Ringgit Malaysia), and in order to facilitate a comparison over time, the consumer price index is used to deflate all the variables to obtain their values at the 2010 constant price. Table 2 shows the summary statistics of the input and output variables, which consists of the mean, the median, the minimum and maximum values, and the standard deviations. The findings show the output prices of Malaysian foreign banks are higher than domestic banks. Interestingly, the mean price of capital is found to be higher among the foreign banks than their counterparts. The descriptive statistics show that domestic banks dominate the foreign banks in terms of both the input and output variables. For instance, both the outputs for the domestic banks are higher by 73 percent as compared to the foreign banks, while the inputs are higher by 70 to 76 percent. The average total loans and advances for the domestic banks are RM23,584 million, while the foreign banks register total loans of RM3,607 million.

\section{Empirical Results of Efficiency}

Table 3 reports the mean efficiency based on the averaging of the estimated effi-

Table 3. Efficiency Scores of the Common Frontier (2006-2014)

\begin{tabular}{ccccccc}
\hline & \multicolumn{3}{c}{ Cost Efficiency } & \multicolumn{3}{c}{ Profit Efficiency } \\
\cline { 2 - 7 } Year & $\begin{array}{c}\text { All } \\
\text { Banks }\end{array}$ & Domestic & Foreign & $\begin{array}{c}\text { All } \\
\text { Banks }\end{array}$ & Domestic & Foreign \\
\hline 2003 & 61.58 & 65.34 & 59.27 & 58.93 & 64.77 & 55.38 \\
2004 & 59.8 & 59.76 & 59.82 & 52.34 & 55.67 & 50.3 \\
2005 & 59.74 & 65.59 & 56.14 & 54.59 & 61.4 & 50.39 \\
2006 & 61.37 & 65.58 & 58.78 & 53.24 & 56.87 & 51.01 \\
2007 & 56.9 & 60.93 & 54.42 & 47.19 & 55.43 & 42.12 \\
2008 & 62.2 & 66.15 & 59.77 & 52.52 & 61.79 & 46.81 \\
2009 & 58.85 & 67.54 & 53.5 & 46.33 & 62.87 & 36.16 \\
2010 & 56.23 & 73.44 & 45.65 & 49.03 & 69.25 & 36.59 \\
2011 & 58.19 & 76.73 & 46.78 & 51.32 & 71.66 & 38.81 \\
2012 & 64.99 & 86.76 & 51.59 & 59.08 & 79.86 & 46.29 \\
2013 & 63.22 & 89.49 & 47.05 & 58.99 & 92.13 & 38.6 \\
2014 & 66.26 & 90.77 & 51.18 & 65.94 & 93.85 & 48.77 \\
Mean & 60.74 & 72.34 & 53.66 & 54.13 & 68.80 & 45.10 \\
\hline
\end{tabular}


Table 3. Efficiency Scores of the Common Frontier (2006-2014)

\begin{tabular}{ccccccc}
\hline & \multicolumn{3}{c}{ Cost Efficiency } & \multicolumn{3}{c}{ Profit Efficiency } \\
\cline { 2 - 7 } Year & $\begin{array}{c}\text { All } \\
\text { Banks }\end{array}$ & Domestic & Foreign & $\begin{array}{c}\text { All } \\
\text { Banks }\end{array}$ & Domestic & Foreign \\
\hline 2003 & 61.58 & 65.34 & 59.27 & 58.93 & 64.77 & 55.38 \\
2004 & 59.8 & 59.76 & 59.82 & 52.34 & 55.67 & 50.3 \\
2005 & 59.74 & 65.59 & 56.14 & 54.59 & 61.4 & 50.39 \\
2006 & 61.37 & 65.58 & 58.78 & 53.24 & 56.87 & 51.01 \\
2007 & 56.9 & 60.93 & 54.42 & 47.19 & 55.43 & 42.12 \\
2008 & 62.2 & 66.15 & 59.77 & 52.52 & 61.79 & 46.81 \\
2009 & 58.85 & 67.54 & 53.5 & 46.33 & 62.87 & 36.16 \\
2010 & 56.23 & 73.44 & 45.65 & 49.03 & 69.25 & 36.59 \\
2011 & 58.19 & 76.73 & 46.78 & 51.32 & 71.66 & 38.81 \\
2012 & 64.99 & 86.76 & 51.59 & 59.08 & 79.86 & 46.29 \\
2013 & 63.22 & 89.49 & 47.05 & 58.99 & 92.13 & 38.6 \\
2014 & 66.26 & 90.77 & 51.18 & 65.94 & 93.85 & 48.77 \\
Mean & 60.74 & 72.34 & 53.66 & 54.13 & 68.80 & 45.10 \\
\hline
\end{tabular}

ciency scores by the number of years of our study period. Generally, the results indicate that there is much room for improvement in both types of efficiency, and profit inefficiency is higher than cost inefficiency in the Malaysian banking market. It is interesting to point out that the cost efficiency gap between the domestic and foreign banks is seen more clearly than the profit efficiency.

The findings of this study contradict the results of the previous studies on Malaysian banks. Matthew and Mahadzir Ismail (2006) and Ong et al. (2011) support the contention that foreign banks are more efficient than domestic banks; however the results of this study suggest that throughout the study period, the foreign banks exhibited a lower level of efficiency than the domestic banks. The difference in the outcome could be due to differences in the selection of our sample; while the latter and the former covers the periods from 1994 to 2000 and 2002 to 2009, this study covers the period from 2003 to 2014. Nevertheless, when a comparison between bank and bank is made, this study tends to offer support to the contention that the foreign banks are more efficient than the domestic banks.

It is noteworthy to point out the efficiency performance of the Malaysian banks during the years 2004 and 2007; the figures reveal the worst performance for both types of banks. A decline of 2 percent and 9 percent in cost and profit efficiency respectively are registered in 2004; while in 2009, a decline of 3.4 percent is recorded for cost efficiency. Even though the overall profit efficiency improves slightly by 1.1 percent in 2009 , it is not reflected in the foreign banks' performance, as the banks were worse off by 
11 percent when compared to the previous year. The efficiency performance of the foreign banks declined in 2009, which could be due to the immediate effects of the sub-prime mortgage crisis in 2008. The largest performance gap between both types of banks is recorded in 2013; whereby the cost efficiency performance of the domestic banks is at 90 percent, while inefficiency scores for the foreign banks are found to be relatively high at 57 percent. In other words, on average; foreign banks waste about 57 percent of their input to produce the desired outputs. Contrary to the aggregate efficiency scores as presented in Table 3, the findings in Table 4 and Table 5 yield striking evidence; the results reveal that for the efficiency performance for each individual bank, the individual foreign banks are more efficient than the individual domestic banks.

From Table 8, the results indicate that the Malaysian banking industry has been characterized by a large asymmetry among the banks, with their average cost efficiency scores ranging between 7.73 percent (TokyoMitsubishi UJF Bank) and 100 percent (AmBank, Maybank, Public Bank, Standard Chartered Bank, Deustche Bank, the Nova Scotia Bank, Bangkok Bank and Bank of China) over the period from 2000 to $2011 .^{8}$ The highest efficiency scores (100 percent) are recorded in 2005 (Bank of China); 2007 (Deustche Bank); 2008 (Standard Chartered Bank); and 2012 to 2014 (AmBank, Maybank, Public Bank, the Nova Scotia Bank, and Bangkok Bank) while the lowest score $(7.73$ percent) is found in 2014. The results further show that the domestic banks are more cost efficient than the foreign banks by 6 percent to 43 percent throughout the period from 2003 to 2014; except for 2004 where both the foreign and domestic banks are slightly indifferent in terms of their cost efficiency performance. Next, Table 5 illustrates the profit efficiency performance of the Malaysian commercial banks, and clearly the results show that the domestic banks are more profit efficient than the foreign banks by a wide range of 5 percent to 54 percent.

Generally, the results of the profit efficiency of the Malaysian banks are mirrored from the cost efficiency performance of the banks i.e. the largest performance gap between both groups of banks is found to be more prominent in recent years. For instance, in 2013, the profit efficiency scores of the domestic banks (92 percent) is almost three times the score of the foreign banks (39 percent). However, in terms of the cost efficiency and profit efficiency performance of the individual banks respectively; more of the foreign banks are classified into the group of efficient banks, as compared with the domestic banks. As an example, the foreign banks are found to be the most profit efficient banks in 2003 (AmBank, Bangkok Bank, Bank of America and Bank of China); 2004 (Bangkok Bank, and Bank of China); 2005-2006 (Bank of America and Bank of China); 2007 (Deustche Bank); 2008 (Standard Chartered Bank); 2010 (Standard Chartered Bank); 2011 (Standard Chartered Bank, and the Nova Scotia Bank); 2012 (AmBank, UOB Bank, the Nova Scotia Bank, and Bangkok Bank); 2013 (AmBank, CIMB Bank, Hong Leong Bank, Public Bank, and the Nova Scotia Bank); and 2014 (AmBank, CIMB Bank, Hong Leong Bank, Maybank, Public Bank, UOB Bank, Deustche Bank, and the Nova Scotia Bank).?

${ }^{8}$ The banks in bold refer to the domestic Malaysian banks. 


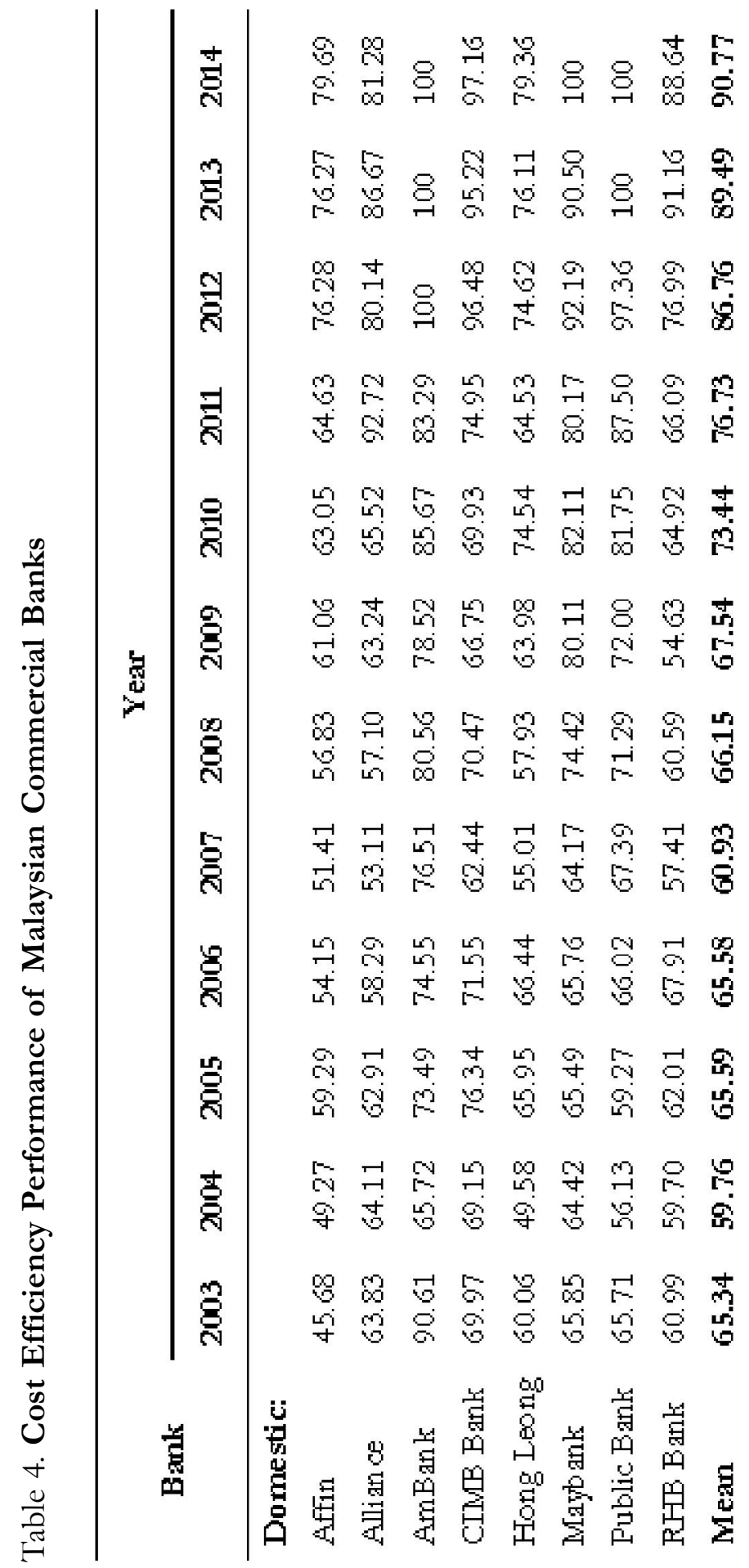




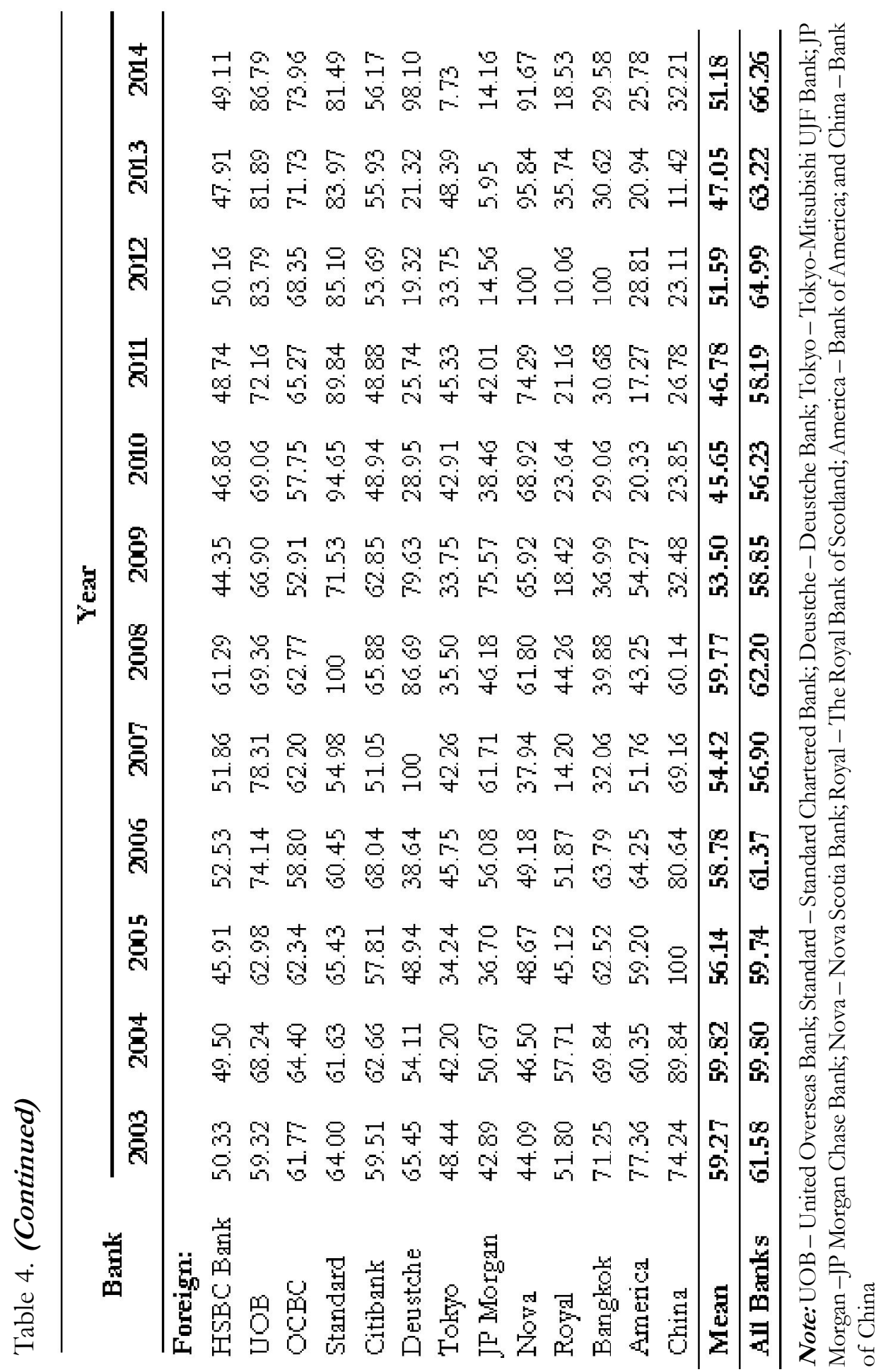




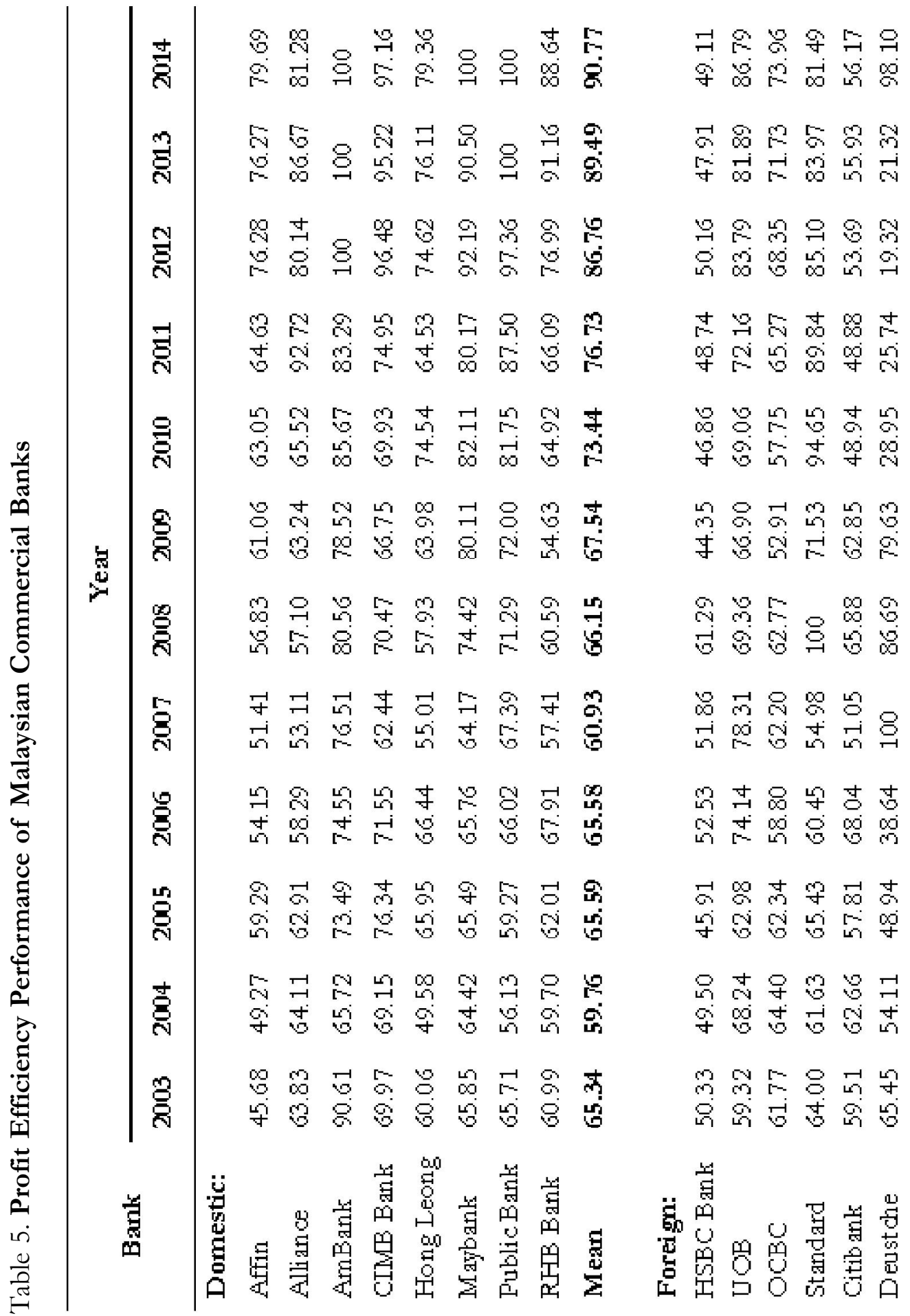




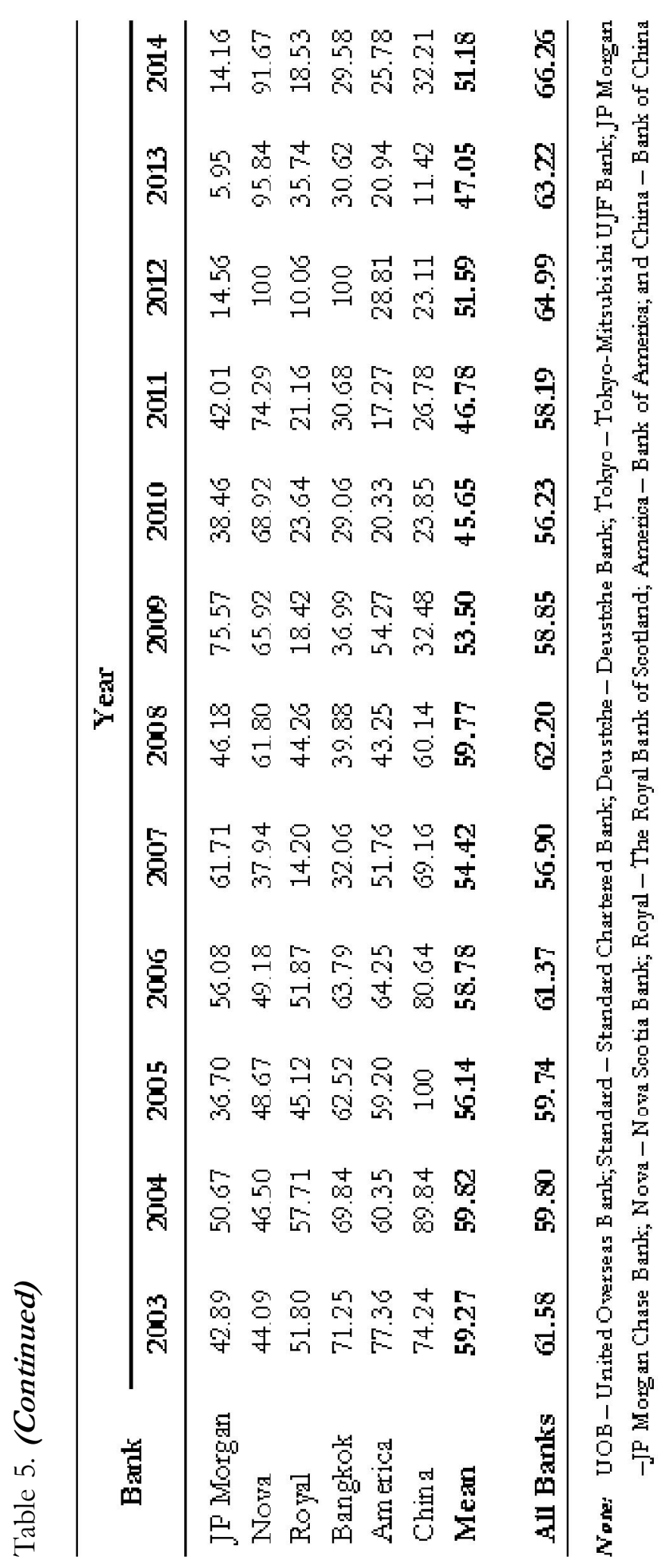


Empirical Results of Competition

Basically, the results in Table 6 suggest that a higher concentration leads to a lower degree of market power; even though the banking market is highly concentrated, it does not lead to anti-competitive conduct. Following the mixed results from the Lerner index between 2007 and 2014; banking competition increased considerably from 2012 to 2014. Thus, one can observe the evolution towards stronger banking competition during the recent period. The banking competition is at its highest value in 2014, when the Lerner index recorded its lowest value, at 0.4344 .

\section{Empirical Results of Competition and Efficiency}

This section reports the empirical results of the Granger causality tests between competition and efficiency presented in Table 7 and Table 8. These results are based on the panel least squares and are White corrected (White 1980). Competition, as represented by the inverse measure of the Lerner index of monopoly power, is regressed upon the lagged cost or profit efficiency as well as the lagged competition, and the results are presented in Panel A; while Panel B reports the empirical findings of the reverse causality running from competition to efficiency.

Table 6. Concentration Ratios and Competition indices (2003-2014)

\begin{tabular}{lccc}
\hline Year & $\begin{array}{c}\text { Concentration } \\
\text { Ratios }\left(\mathbf{C R}_{2}\right)\end{array}$ & $\begin{array}{c}\text { Hirschman- } \\
\text { Herfindahl Index }\end{array}$ & Lerner Index \\
\hline 2003 & 0.4724 & 1177.45 & 0.5227 \\
2004 & 0.4840 & 1173.29 & 0.5215 \\
2005 & 0.4776 & 1132.63 & 0.5291 \\
2006 & 0.5111 & 1165.49 & 0.5554 \\
2007 & 0.5199 & 1178.90 & 0.5012 \\
2008 & 0.5223 & 1189.91 & 0.4549 \\
2009 & 0.5446 & 1239.58 & 0.4782 \\
2010 & 0.5386 & 1224.44 & 0.4639 \\
2011 & 0.5278 & 1258.15 & 0.5068 \\
2012 & 0.4949 & 1198.36 & 0.4669 \\
2013 & 0.5339 & 1338.67 & 0.4357 \\
2014 & 0.5394 & 1346.87 & 0.4344 \\
\hline
\end{tabular}

${ }^{9}$ The banks in bold refer to the domestic Malaysian banks. 
Table 7. Granger-causality Tests - Lerner Index and Cost Efficiency

PANEL A: Dependent variable - Cost Efficiency (CE)

\begin{tabular}{lccc}
\hline Model & All Banks & Domestic Banks & Foreign Banks \\
\hline constant & $0.2212^{*}$ & 0.0835 & $0.1015^{* *}$ \\
CE (-1) & $0.3163^{*}$ & $0.6627^{*}$ & $0.4871^{*}$ \\
CE (-2) & 0.0981 & 0.0773 & $0.2680^{*}$ \\
$\Sigma$ coefficients: & 0.4144 & 0.74 & 0.7551 \\
Lerner (-1) & $-0.2303^{*}$ & -0.0252 & $-0.2539^{*}$ \\
Lerner (-2) & $0.1428^{*}$ & 0.0289 & $0.1827^{* *}$ \\
$\Sigma$ coefficients: & -0.0875 & 0.0037 & -0.0712 \\
R-squared & 0.5575 & 0.4619 & 0.4407 \\
Adjusted R-squared & 0.4745 & 0.4332 & 0.4228 \\
F-statistics & 6.7198 & 16.0975 & 24.6315 \\
Prob (F-statistics) & 0.0000 & 0.0000 & 0.0000
\end{tabular}

PANEL B: Dependent variable - Lerner Index

\begin{tabular}{lccc}
\hline Model & All banks & Domestic banks & Foreign Banks \\
\hline constant & 0.0373 & 0.0835 & -0.0241 \\
CE (-1) & 0.0805 & 0.1372 & -0.0106 \\
CE (-2) & $0.2863^{*}$ & 0.1096 & $0.2082^{* *}$ \\
$\Sigma$ coefficients: & 0.3668 & 0.2468 & 0.1976 \\
Lerner (-1) & $0.4428^{*}$ & 1.1065 & $0.6019^{*}$ \\
Lerner (-2) & $0.2352^{*}$ & 0.0389 & $0.2737^{*}$ \\
$\Sigma$ coefficients: & 0.678 & 1.1454 & 0.8756 \\
R-squared & 0.7856 & 0.5905 & 0.6427 \\
Adjusted R-squared & 0.7455 & 0.5686 & 0.6312 \\
F-statistics & 19.5531 & 27.0407 & 56.2116 \\
Prob (F-statistics) & 0.0000 & 0.0000 & 0.0000 \\
\hline
\end{tabular}

Note: $*$; ** - significant at 1 and 5 per cent significance level respectively 
The results reported in Panel A, Table 7 may seem surprising at first glance, as a positive link between cost efficiency and competition seems more intuitive. The results imply that cost efficient banks may have increased their market power and caused a decrease in banking competition. The negative efficiency-competition link seems to be consistent with the efficient structure hypothesis (Demsetz 1973; Peltzman 1977; and Smirlock 1985) and quiet-life hypothesis (Hicks 1935) whereby efficient banks, with the most cost efficient practices, tend to exploit their market power. The results imply that efficient banking systems are also the least competitive, as the particular banks benefit from economies of scale and achieve a higher degree of market power. Thus, a noncompetitive banking market permits bank managers to enjoy a quiet life where costs are not kept under control. Similar results are reported by Pruteanu-Podpeira et al. (2008) in the Czech banking sector; Yildirim and Philippatos (2006) and Koetter et al. (2008) for U.S. banks; as well as several studies on the European Union (EU) banking market, such as Weill (2004), Maudos and de Guevara (2007), Casu and Girardone (2006, 2009). Schaeck and Cihak (2008) confirm the negative running causality from cost efficiency to competition within the European and U.S. banking markets.

Panel B in Table 7 and Table 8 shows the Lerner index negatively caused the banking efficiency, thereby indicating that competition in a banking system yields positive impacts to the efficiency performance of banks. Increased competition would favor banking efficiency, by providing incentives to manager to cut costs, in order to remain profitable. Theoretically, industrial organization literature supports the notion that competition yields positive effects to efficiency. This notion is further supported by the banking literature, which mentions that efficient banks have better screening and monitoring procedures. As a result, bad loan problems can be avoided (Berger and DeYoung 1997; Williams 2004). The positive causality from competition to efficiency lends support to the quiet-life hypothesis (Hicks 1935), x-efficiencies hypothesis (Leibenstein 1966) and structure-conduct-performance hypothesis (Bain 1951). In the words of Grossman and Hart (1983), under the setting of asymmetric information and uncertainty, competitive pressures serve as the most effective instrument in fostering productive efficiency. Thus, managers have less incentive to manage the firm efficiently in the case of low market competition, because the firm has the ability to generate sufficient profits to justify the management. Koetter et al. (2008) supports the negative effect of competition on efficiency, in the context of cost efficiency and the positive effect in the case of profit efficiency.

Interestingly, Panel A in Table 8 reports otherwise, and this has led to a puzzle in the context of the efficiency-competition nexus among Malaysian commercial banks. The results indicate that an increase in profit efficiency causes an increase in banking competition; hence, the positive link appears to be due to the nature of the efficiency itself. This implies that, despite being profit efficient, Malaysian banks are not exploiting their market power. The mixed evidence suggests that policy makers need to be more selective in promoting or pursuing policies that enhance the efficiency's performance, as it could result in a trade-off between efficiency and competition. 
Table 8. Granger-Causality Tests - Lerner Index and Profit Efficiency

PANEL A: Dependent variable - Profit Efficiency (PE)

\begin{tabular}{lccc}
\hline Model & All banks & Domestic banks & Foreign banks \\
\hline constant & $0.1911^{*}$ & 0.1832 & $0.09105^{* *}$ \\
PE (-1) & $0.34754^{*}$ & $0.9323^{*}$ & $0.5629^{*}$ \\
PE (-2) & -0.1321 & 0.1063 & 0.1076 \\
$\Sigma$ coefficients: & 0.21544 & 1.0386 & 0.6705 \\
Lerner (-1) & $-0.1827^{*}$ & -0.1509 & -0.1519 \\
Lerner (-2) & $0.1701^{* *}$ & -0.1309 & 0.1222 \\
$\Sigma$ coefficients: & -0.0126 & -0.2818 & -0.0297 \\
R-squared & 0.5306 & 0.6565 & 0.3509 \\
Adjusted R-squared & 0.4427 & 0.6382 & 0.3301 \\
F-statistics & 6.0311 & 35.8429 & 16.8952 \\
Prob (F-statistics) & 0.0000 & 0.0000 & 0.0000
\end{tabular}

PANEL B: Dependent variable - Lerner Index

\begin{tabular}{|c|c|c|c|}
\hline Model & All banks & Domestic banks & Foreign banks \\
\hline constant & $0.1006^{* *}$ & -0.0740 & 0.0083 \\
\hline PE $(-1)$ & -0.6441 & -0.1734 & -0.0756 \\
\hline $\operatorname{PE}(-2)$ & $0.3241 *$ & 0.1821 & $0.2467 *$ \\
\hline$\Sigma$ coefficients: & -0.3200 & 0.0087 & 0.1711 \\
\hline Lerner $(-1)$ & $0.4191 *$ & $0.9032 *$ & 0.5741 \\
\hline Lerner $(-2)$ & $0.2349 *$ & 0.2121 & 0.2764 \\
\hline$\Sigma$ coefficients: & 0.6540 & 1.1153 & 0.8505 \\
\hline R-squared & 0.7857 & 0.5941 & 0.6488 \\
\hline Adjusted R-squared & 0.7455 & 0.723 & 0.3305 \\
\hline F-statistics & 19.5588 & 27.4351 & 16.8951 \\
\hline Prob (F-statistics) & 0.0000 & 0.0000 & 0.0000 \\
\hline
\end{tabular}

Note:*; ** - significant at 1 and 5 per cent significance level respectively 


\section{Conclusion}

To sum up briefly, this study provides evidence of the positive link between banking competition and banking efficiency in developing countries by focusing on the Malaysian banking industry. Theoretically, intense competition compels firms to make greater efforts in order to improve their efficiency. With no or less competitive pressure, firms prefer to enjoy a quiet life by taking their customers for granted, and they lack the proper incentives to increase their efficiency and productivity. By ensuring only the most competitive and innovative firms are able to stay steadfast on the efficient production frontier, competition improves consumer welfare. Competition benefits customers, by making firms more efficient, inducing firms to compete via price, improve the quality of their services and to innovate more. Nevertheless, the impact of competition depends on many factors, such as the nature and structure of the industry. The policies taken by the authorities should be of a continual basis, the effects of government policies should be allowed to be realized over the long term in order to see the actual effects of banking competition. Due to the flexibility over time, both efficiencies can be improved in a longer time period.

The results of this study offer cautions to the authorities; they show that efficiency and competition cannot be achieved with a single policy directive. This study recommends that the authorities should tackle the issue by addressing policies based on a continual basis. In this vein, it is important for the government to make continuous efforts, and by persistently promoting competition in the banking industry, the competitiveness of the banking industry will result in higher efficiency and better innovation that eventually leads to a greater variety of products, lower prices, higher consumer welfare, lower market power and better access to financial products and services. Adding to that, a heightened sense of competition also would encourage the banks to identify new lending opportunities, while expanding their customer base in order to generate income. By ensuring the optimal competitive conditions in the Malaysian banking industry, the authorities can ensure that it will have positive results on the performance of the banks. For instance, strategies to promote competition by reducing the price of financial services and products may benefit the banking market (Fang et al. 2011). Thus, the banking liberalization which is taking place in the Malaysian banking sector seems timely, given the results of this study. The acceleration in the banking liberalization has raised concerns about the increased concentration, and implications for the increased market power. Nevertheless, it is important to highlight that the relationship between competition and efficiency is more complex (Claessens and Leaven 2004).

\section{Acknowledgement}

This work was supported by Ministry of Higher Education and Universiti Malaysia Sarawak [grant numbers Research Acculturation Collaborative Effort RACE/E (3)/1250/2015(06)]. 


\section{References}

Abd-Majid, M. S., and F. Maulana. 2012. A comparative analysis of the productivity of Islamic and conventional mutual funds in Indonesia: Data envelopment analysis (DEA) and general least square (GLS) Approaches. Gadjah Mada International Journal of Business 14 (2): 183-208.

Angelini, P., and Cetorelli. N. 2003. The effects of regulatory reform on competition in the banking industry. Journal of Money, Credit, and Banking 35 (5): 663-684.

Bain, J. S. 1951. Relation of profit rate to industry concentration: American manufacturing, 1936-1940. The Quarterly Journal of Economics 65 (3): 293-324.

Barajas, A., S. Roberto, and S. Natalia. 2000. The impact of liberalization and foreign investment in Colombia's financial sector. Journal of Development Economics 63: 157-196.

Baumol, W. J. 1982. Contestable market: An uprising in the theory of market structure. The American Economic Review 7 (1): 1-15.

Berg, S. A., and M. Kim. 1994. Oligopolistic interdependence and the structure of production in banking: An empirical evaluation. Journal of Money, Credit, and Banking 26 (2): 309-322.

Berger, A. N. 1995. The profit-structure relationship in banking: Tests of market power and efficient structure hypotheses. Journal of Money, Credit, and Banking 27: 404-431.

Berger, A.N., and R. DeYoung. 1997. Problem loans and cost efficiency in commercial banks. Journal of Banking and Finance 21: 849-870.

Berger, A. N., and D. B. Humphrey. 1992. Megamergers in banking and the use of cost efficiency as an antitrust defense. Antitrust Bulletin 37: 541-600.

Berger, A. N., and D. B. Humphrey. 1997. Efficiency of financial institutions: International survey and directions for future research. European Journal of Operational Research 98: 175-212.

Berger, A. N., and L. J. Mester. 2003. Explaining the dramatic change in performance of US banks: Technological change, deregulation, and dynamic changes in competition. Journal of Financial Intermediation 12: 57-95.

Berger, A. N., R. DeYoung, H. Genay, and G. F. Udell. 2000. Globalization of financial institutions: Evidence from cross-border banking performance. Brookings-Wharton Papers on Financial Services 3: 23-120.

Bureau Van Dijk IBCA. 2000. Bank Scope Database. New York: Bureau Van Dijk IBCA.

Casu, B., and C. Giradone. 2006. Bank competition, concentration, and efficiency in the single European market. The Manchester School 74 (4): 441-468.

Casu, B., and C. Girardone. 2009. Testing the relationship between competition and efficiency in banking: A panel data analysis. Economics Letters 105: 134-137.

Central Bank of Malaysia. 1999. The Central Bank and the Financial System in Malaysia - A Decade of Change. Kuala Lumpur: Central Bank of Malaysia.

Central Bank of Malaysia. 2015. The 2014 Bank Negara Malaysia Annual Report. Kuala Lumpur: Central Bank of Malaysia.

Charnes, A., W. W. Cooper, and E. Rhoades. 1978. Measuring the efficiency of decision making units. European Journal of Operational Research 2: 429 - 444. 
Chinn, M. D. and H. Ito. 2006. What matters for development economics? Journal of Development Economics 81 (1): 163-192.

Chung, Y., R. Fare, and S. Grosskopf. 1997. Productivity and undesirable outputs: A directional distance function approach. Journal of Environmental Management 51: 229-240.

Claessens, S. 2009. Competition in financial sector: Overview of competition policies. World Bank Research Observer 24 (1): 83-118.

Claessens, S., and L. Laeven. 2004. What drives bank competition? Some international evidence? Journal of Money, Credit, and Banking 36: 562-583.

Claessens, S., and L. Laeven. 2005. Financial dependence, banking sector competition, and economic growth. Journal of the European Economic Association 3 (1): 179-207.

Claessens, S., and N. van Horen. 2013. Foreign banks: Trends and impact. Journal of Money, Credit and Banking 46 (1) (February): 295-326.

Claessens, S., A. Demirguc-Kunt, and H. Huizinga. 2001. How does foreign entry affect domestic banking markets? Journal of Banking and Finance 25: 891-911.

Clarke, G., R. Cull, M. Soledad, M. Peria, and S. Sa'nchez. 2001. Foreign bank entry: Experience, implications for developing countries, and agenda for further research. Policy Research Working Paper Series 2698. The World Bank.

Crystal, J. S., B. G. Dages, L. and L. S. Goldberg. 2002. Has foreign bank entry led to sounder banks in Latin America? Federal Reserve Bank of New York Current Issues in Economics and Finance 8 (1).

Dages, B. G., L. S. Goldberg, and D. Kinney. 2000. Foreign and domestic bank participation in emerging markets: Lessons from Mexico and Argentina. Federal Reserve Bank of New York Economic Policy Review 6 (3): 17-36.

de la Torre, A., M. S. Martinez-Peria, and S. Schmukler. 2010. Bank involvement with SMEs: Beyond relationship lending. Journal of Banking and Finance 34: 2280-93.

Demsetz, H. 1973. Industry structure, market rivalry, and public policy. Journal of Law and Economics 16 (1): $1-9$.

Denizer, C. A., M. Dinc, and M. Tarimcilar. 2000. Measuring banking efficiency in the pre- and postliberalization environment: Evidence from the Turkish banking system. Policy Research Working Papers Series 2476. The World Bank.

Detragiache, E. and P. Gupta. 2004. Foreign banks in emerging market crisis: Evidence from Malaysia. IMF Working Paper WP 04/129. International Monetary Fund.

Dogan, E., and D. K. Fausten. 2003. Productivity and technical change in Malaysian banking: 1989-1998. Asia Pacific Financial Markets 10: 205-237.

Fang, Y., I. Hasan, and K. Marton. 2011. Bank efficiency in South-Eastern Europe. Economics of Transition 19 (3): 495-520.

Fernández de Guevara, J., J. Maudos, and F. Pérez. 2005. Market power in European banking sector. Journal of Financial Services Research 27 (2): 109 - 37.

Grigorian, D. A., and V. Manole. 2002. Determinants of commercial bank performance in transition: An application of data envelopment analysis. IMF Working Paper No. 02/146. International Monetary Fund. 
Grossman, S., and O. Hart. 1983. An analysis of the principal-agent problem. Econometrica 51: 7-45.

Hasan, I., and K. Marton. 2003. Development and efficiency of the banking sector in a transitional economy: Hungarian experience. Journal of Banking and Finance 27 (12): 2249-2271.

Havrylchyk, O. 2006. Efficiency of the Polish banking industry: Foreign versus domestic banks. Journal of Banking and Finance 30: 1975-1996.

Hermes, N., and V. Nhunq. 2008. The impact of financial liberalization on bank efficiency: Evidence from Latin America and Asia. Applied Economics 42 (26): 1-21.

Hicks, J. R. 1935. Annual survey of economic theory: The theory of monopoly. Econometrica 3 (1): 1-20.

Isik, I., and M. K. Hasan. 2002. Technical, scale, and allocative efficiencies of Turkish banking industry. Journal of Banking and Finance 26: 719-766.

Isik, I., and M. K. Hasan. 2003. Efficiency, ownership, and market structure, corporate control and governance in the Turkish banking industry. Journal of Business Finance and Accounting 30 (9 and 10): $1363-1421$

Jeon, B. M., and J. Wu. 2014. The role of foreign banks in monetary policy transmission: Evidence from Asia during the crisis of 2008-09. HKIMR Working Paper No. 01/2014, Hong Kong Institute for Monetary Research.

Jeon, B. N., M. P. Olivero, and J. Wu. 2011. Do foreign banks increase competition? Evidence from emerging Asia and Latin America. Journal of Banking and Finance, 35 (4): 856-875.

Klein, M. 1971. A theory of banking firm. Journal of Money, Credit, and Banking 7: 205-218.

Koetter, M., J. W. Kolari, and L. Spierdijk. 2008. Testing the 'quiet life' of U.S. banks with adjusted Lerner indices. Proceedings of Federal Reserve Bank of Chicago (May): 234-252.

Koeva, P. 2003. The performance of Indian banks during financial liberalization. Working Paper No. 150. International Monetary Fund.

Kose, A.M., and E. S. Prasad, and M. E. Terrones. 2009. Does openness to international financial flows raise productivity growth? Journal of International Money and Finance 28 (4): 554-580.

Kraft, E., R. Hofler, and J. Payne. 2006. Privatization, foreign bank entry and bank efficiency in Croatia: A Fourier-flexible function stochastic cost frontier analysis. Applied Economics 38: 20-75.

Leibenstein, H. 1966. Allocative efficiency 'versus x-efficiency. American Economic Review 56: 392-415.

Lensink, R., A. Meesters, and I. Naaborg. 2008. Bank efficiency and foreign ownership: Do good institutions matter? Journal of Banking and Finance 32: 834-844.

Levy-Yeyati, E., and A. Micco. 2007. Concentration and foreign penetration in Latin American banking sectors: Impact on competition and risk. Journal of Banking and Finance 31: 1633-1647.

Liao, C. S. 2010. Are foreign banks in developing countries more productive? The case of Taiwan. Journal of International and Global Economic Studies 3 (2): 63-74.

Lindgren, C. J., J. T. Tomás, C. E. Baliño, A. M. Gulde, M. Quintyn, and L. Teo. 1999. Financial sector crisis and restructuring: Lessons from Asia. Occasional Paper 188, International Monetary Fund.

Mason, E. S. 1939. Price and production policies of large-scale enterprises. American Economic Review 29: 61-74.

Matthews, K., and M. Ismail. 2006. Efficiency and productivity growth of domestic and foreign commercial banks in Malaysia. Working Paper No. E2006. Cardiff Business School. 
Maudos, J., and J. Fernández de Guevara. 2007. The cost of market power in banking: Social welfare loss vs. cost inefficiency. Journal of Banking and Finance 31 (7): 2103-2125.

McKinnon, R. 1973. Money and Capital in Economic Development. Washington DC: Brookings Institution.

Mlambo, K., and M. Ncube. 2011. Competition and efficiency in the banking sector in South Africa. African Development Review 23 (1): 4-15.

Mlima, A. Z., and L. Hjalmarrson, L. 2002. Measurements of inputs and outputs in the banking industry. Tanzanet Journal 3 (1): 12-22.

Moguillanski G., R. Studart, and S. Vergara. 2004. Foreign banks in Latin America: A paradoxical result. CEPAL Review 82: 19-35.

Mohd-Tahir, I., N. M. Abu-Bakar, and S. Haron. 2010. Cost and profit efficiency of the Malaysia commercial banks: A comparison between domestic and foreign banks. International Journal of Economics and Finance 2 (1): 186-197.

Monti, M. 1972. Deposit, credit, and interest rate determination under alternative bank objectives. In Szego, G.P. and Shell, K. (Eds.). Mathematical Methods in Investment and Finance. Amsterdam: NorthHolland.

Morgan, D. P., and P. E. Strahan. 2004. Foreign bank entry and business volatility: Evidence from U.S. states and other countries. In Ahumada, L. A., J. R. Fuentes, and N. Loayza (Series Editor) and Klaus Schmidt-Hebbel (Ed.). Banking Market Structure and Monetary Policy. Chile: Central Bank of Chile: 241-270.

Njie, M. 2006. The impact of financial liberalization on bank spreads in Malaysia. Journal of Economic Cooperation 27 (3): 163194.

Okuda, H., and H. Hashimoto. 2004. Estimation cost functions of Malaysian commercial banks: The differential effects of size, location and ownership. Asian Economic Journal 18 (3): 233-259.

Olivero, M. P., Y. Li, and B. N. Jeon. 2009. Consolidation in banking and the lending channel of monetary transmission: Evidence from Asia and Latin America. Working Paper. LeBow College of Business, Drexel University.

Omar, M. A., M. S. Abd-Majid, and R. Rulindo. 2007. Efficiency and productivity performance of the national private banks in Indonesia. Gadjah Mada International Journal of Business 9 (1): 1-18.

Ong, T. S., Y. T. Lim, and B. H. Teh. 2011. A comparison on efficiency of domestic and foreign banks in Malaysia: A DEA approach. Business Management Dynamics 1 (4): 33-49.

Peltzman, S. 1977. The gains and losses from industrial concentration. Journal of Law and Economics 20: 22963.

Pruteanu-Podpiera, A., L. Weill, and F. Schobert. 2008. Banking competition and efficiency: a micro-data analysis on the Czech banking industry. Comparative Economic Studies 50: 253-73.

Saez-Fernandez'F. J., A. J. Picazo-Tadeo, and M. Beltrán-Esteve. 2015. Assessing the performance of the Latin American and Caribbean banking industry: Are domestic and foreign banks so different? Cogent Economics and Finance 3 (1): 1-16.

Saif, I., and H. Yaseen. 2005. The efficiency of foreign and domestic banks in MENA region: Evidence on economies of scale and scope. Paper. ERF 12th Annual Conference: Reform - Made to Last, Cairo, Egypt.

Schaeck, K., and M. Cihak. 2008. How does competition affect efficiency and soundness in banking? New empirical evidence. ECB Working Paper No. 932. European Central Bank. 
Sealey, C., and J. T. Lindley. 1977. Inputs, outputs, and a theory of production and cost at depository financial institution. Journal of Finance 32: 1251-1266.

Shaffer, S. 1993. A test of competition in Canadian banking. Journal of Money, Credit, and Banking 25 (1): 49-61.

Shaw, E. S. 1973. Financial Deepening in Economic Development. New York: Oxford University Press.

Smirlock, M. 1985. Evidence on the (non) relationship between concentration and profitability in banking. Journal of Money, Credit, and Banking 17 (1): 69-83.

Sufian, F., and M. S. Abd-Majid. 2007. Bank mergers performance and the determinants of Singaporean banks' efficiency: An application of two-stage banking models. Gadjah Mada International Journal of Business 9 (1): 19-39.

The Star Online. 9 January 2015. Cracks in CIMB, RHB, MBSB merger plan: EPF may not be able to vote. [http://www.thestar.com.my/Business/Business-News/2015/01/09/ Cracks-in-bank-mergerplan/?style=biz]

Weill, L. 2004. On the relationship between competition and efficiency in the EU banking sectors. Kredit und Kapital 37 (3): 329-352.

Wezell, T. 2010. Bank efficiency amid foreign entry: Evidence from the Central American region. IMF Working Paper WP/10/95. International Monetary Fund.

White, H. 1980. A heteroskedasticity-consistent covariance matrix estimator and a direct test for heteroskedasticity. Econometrica 48 (4): 817-838.

Williams, J. 2004. Determining management behavior in European banking. Journal of Banking and Finance 28: 2427-2460.

Wu, J., B. N. Jeon, and A. C. Luca. 2010. Foreign bank penetration, resource allocation and economic growth: Evidence from emerging economies. International Journal of Economic Integration 25 (1): 167 193.

Yildirim, H. S., and G. C. Philippatos. 2006. Restructuring, consolidation and competition in Latin American banking markets. Journal of Banking and Finance 31 (3): 629-639.

Yildirim, H. S., and G. C. Philippatos. 2007. Efficiency of banks: Recent evidence from the transition economies of Europe, 1993-2000. The European Journal of Finance 13 (2): 123-143. 